\title{
Corporate social responsibility and corporate governance in Indonesian public listed companies
}

\author{
Siti Rochmah $\mathrm{Ika}^{1,{ }^{,}, \text {Titop Dwiwinarno }}{ }^{2}$, and Ari Kuncara Widagdo ${ }^{3}$ \\ ${ }^{1}$ Accounting Department, Faculty of Economics, Janabadra University, Yogyakarta, Indonesia \\ ${ }^{2}$ Management Department, Faculty of Economics, Janabadra University Yogyakarta, Indonesia \\ ${ }^{3}$ Accounting Department, Faculty of Economics, Sebelas Maret University Solo, Indonesia
}

\begin{abstract}
This study aims to investigate whether theree has been a change in the level of corporate social responsibility (CSR) disclosure and to examine whether corporate governance attributes influence CSR disclosure in corporate annual report of Indonesian public listed companies(PLCs). The annual reports of 115 PLC for two years (2011 and 2012) were analysed using content analysis. Multiple regression analysis was utilized to determine factors influencing CSR disclosure in annual reports. Consistent with expectations, the paired sample t-test showed that there was an increase (significant at the 1 percent level) in the extent of CSR disclosure. The multiple regression analysis revealed that audit committee effectiveness and company's size were positively associated with the extent of CSR disclosure (significant at 5 per cent level). The findings appear to suggest that The Indonesian Capital Market and Financial Institutions Supervisory Agency (Bapepam LK) effforts in promoting CSR through the release of Regulation No X.K.6 in 2012 have had some positive impact on CSR disclosure in annual report. The results also suggest that the involvement of audit committee through its effectiveness in overseeing company's financial reporting could lead to better concern in corporate social activities and hence disclosure in annual reports. This study however, has limitation that should be considered in interpreting the results. The regression model documented an $\mathrm{R}^{2}$ of 21.4 percent, which indicates that almost 80 percent of factors influencing CSR disclosure in Indonesian PLC have not been captured by the model. These other factors may perhaps be indentified in the next research.

Keywords: Corporate social responsibility, corporate social responsibility disclosure, corporate governance, audit committee, audit committee effectiveness.
\end{abstract}

\section{Introduction}

The Indonesian government's incentive to further promote CSR among PLCs is very encouraging. The enactment of Law No 40 in 2007 concerning Limited Liabilities Company and Government Regulation No 47/2012 concerning Corporate Social and

*Corresponding author: ika@janabadra.ac.id 
Environmental Responsibility has made CSR activities mandatory to all companies in Indonesia. In terms of disclosure, Bapepam LK has issued Rule No x.k.6/2012[1 ]concerning Submission of Issuer or Public Company Annual Report. This rule basically provides detailed guideline with respect to the form and content of annual reports of PLC which serve as a source of information for investors and public. In the rule, [1], point $h$, it is stated that the discussion of CSR includes policies, types of programs, and costs, among others related to aspects: (a) environment, (b) labor practices, (c) social and community development, and (d) product safety. This new rulereplaces the previous Rule No X.K.6/2006 [2] in which one of the main changes is the content of CSR disclosure. In the old rule [2], it was only stated that the CSR disclosure "is a description of the activities and costs relating to corporate social responsibility towards society and the environment". Hence it may be expected that after the issuance of the new rule, the content of CSR disclosure among PLC increases.

The purpose of this study is to investigate whether there has been a change in the level of CSR disclosure after the issuance of the new rule and to determine wheteher corporate governance attributes influence CSR disclosure in corporate annual reports of Indonesian PLCs. Unlike previous studies in Indonesia, [3],[4] which haveonly focused on the amount and theme of CSR in a single year, this study extends prior studies by examining if there had been changes in the extent of CSR disclosure in Indonesian PLCs. Examining the level of CSR discosure would give some indications on whether guidelines as stated in the new rule have had some positive effect on corporate social activities.

The present study also examine the influence of corporate governance attributes in CSR disclosure of which is audit committee effectiveness. A number of studies including [5],[6], [7], have examined the association of audit committee andCSR disclosure. Some of these studies examined single charasteristic ofaudit committee, for example proportion of independent non-executive directors sit in audit committee[5]; the presence of audit committee [6]. Likewise, [7] examined some characteristics of audit committe namely audit committe size, expertise, and meeting in influencing CSR dislosure. The examination of these characteristics however may not be adequate to capture the effectiveness of audit committee in overseeing financial reporting quality [8], specifically in terms of the level of CSR disclosure. The present study fills the gap in the literature by utilizing an index to measure audit committee effectiveness as developed by [8]. The index comprises of audit commitee charteristics related to structure, membership, independence, job duties, and disclosure of auditcommittee in company annual reports.

The remainder of the paper is organized as follows. The next section discuss prior relevant literature and hypotheses development. The research method including sample selection and data collection is then explained. Findings and analysis which are followed by concluding remarks are then discussed in the ensuing section.

\section{Literature Review and Hypotheses Development}

A number of studies have been done relating corporate governance to CSR disclosure; for example [4-7], [9-11]. Corporate governance factors that have been investigated in these studies include board size, board independence, CEO duality; board meetings, women on board, audit committee characteristics, and ownership structure (i.e. foreign ownership, managerial ownership, government ownership).In Indonesian context,[4]examined the impact of board size, foreign ownership, firms size, profitability, and leverage on CSR reporting. The study found thatboard size board and firm size have a positive impact on CSR disclosure. [4] however, yet to examine the influence of audit committee in their study. Therefore this paper attempts to fill this gap. 


\subsection{The extent of CSR disclosure}

As stated in the introduction section,[1] regulates the disclosure of information in issuers' and public company's annual reports, which serve as a source of information for shareholders and the public. In terms of CSR, this rule provides guideline with respect to content of the disclosure in annual reports of PLCs which the discussion of CSR includes policies, types of programs, and costs, related to aspects: (a) environment, (b) labor practices, (c) social and community development, and (d) product responsibility. The obligation to prepare the annual report in accordance with the new rule applies for the financial years ended 31 December 2012 onwards. Therefore, with the issuance of [1] rule, PLCs are expected to involve more CSR activities and have more disclosure of CSR in the annual report.

[9] scrutinized the level of CSR disclosure after the introduction of CSR guideline, called Silver Book among Malaysian government-link companies (GLCs). The study found that that there was an increase and statistically significant in the extent of CSR disclosure in year 2007 as compared to 2005. Therefore, it may be expected that the level of CRS disclosure among Indonesian PLCs increases after the issuance o the new rule. The hypothesis is expressed as follow.

H1: There is a significant increase in the extent of CSR disclosure in the annual reports of Indonesian PLCs after the issuance of [1] rule.

\subsection{Board Size}

[5] stated that board of directors is a crucial aspects of corporate governance mechanism relating to its duty in monitoring how the companies business is being properly managed by their agents. Indonesia adopts a two-tier governance model, meaning there are two board structures in the company, board of commissioners (BOC) and board of directors (BOD). $\mathrm{BOC}$ is a shareholder representative whose duty is to provide strategic guidance and give advice to management decision, while BOD is in charge to run the business. The two tier board structure ensures that all commissioners are non-executives. The functions of BOC in two-tier model are similar to those of BOD in a one-tier system.

[12] argued that the CEO will be easier to be controlled and monitored by larger board. However, [13] advocated that as boards grow, they are less likely to function effectively because coordination and information- processing costs outweigh the benefit of having more people's expertise. Empirical studies on the relationship between board size and CSR disclosure are mixed. [10] documented that board size has no association with CSR disclosure. Meanwhile $[5,6,9]$ suggested that board size is positively associated with the extent of CSR disclosure. In Indonesian context, [4] found that board size has a positive and non-linier relationship with the extent of CSR disclosure. The results imply that large boards are able to oversee business operations better than smaller ones; however too large a board makes the process of monitoring ineffective. Thus it is hypothesized that:

$\mathrm{H} 2$ : There is a positive association between a board size and the extent of CSR disclosure in Indonesian PLCs.

\subsection{Board Independence}

In the corporate governance literature, the presence of independent directors is presumed to strengthen the board by monitoring the activity of management. Therefore, it is generally 
believed that with a high proportion of independent directors, the interests of the investors are protected, specifically when arriving at board decision [14]. Several studies have examined the association between board independence and CSR disclosure. [6,7] showed a positive and significant relationship between board independence and CSR disclosure. In Indonesian Stock Exchange (IDX), listing requirements state thatthe number of independent commissioners is at least $30 \%$ of the total BOC members. This requirement can be interpreted as having more independent boards to be more effective in monitoring role. Some studies in Malaysia [5,9] did not find any association between board independence and CSR disclosure, neither did in the US [10]. With these literatures, it is hypothesized that:

H3: There is a positive association between proportion of independent commissioners and the extent of CSR disclosure in Indonesian PLCs.

\subsection{Audit Committee Effectiveness}

The role of audit committee in enhancing corporate governance standard has been well documented by prior studies[e.g. 15,16]. As a committee of the board, its existence relates to oversight responsibility in the area of financial reporting, internal control, and external auditing activity. Therefore, in the agency theory context, it may be expected that effective audit committee are likely to improve financial reporting quality, including the extent of disclosure.

A number of studies have examined the association between audit committee and financial reporting quality using some proxies for financial reporting quality. These proxies include timeliness of reporting [8], level of interim financial disclosure [17], and the extent of CSR disclosure [5-7].[8]found that the effectiveness of audit committee may reduce reporting lag It was found that the existence of an audit committee was significantly and positively related to the extent of CSR disclosure [7]. Although, it appears unlikely that audit committee financial expertise may be linked directly to the understanding of audit committee members of CSR-related information, [6] documented that the number of financial expert on audit committee and the number of audit committee meetings per year were positively associated with the extent of CSR disclosure. Hence, it is hypothesized that:

H4: There is a positive association between audit committee effectiveness and the extent of CSR disclosure in Indonesian PLCs.

\subsection{Ownership Concentration}

According to [11], companies that have dispersed ownership are expected to involvemore in community or social activities since the issue of public accountability is important in these companies. Therefore, it may be expected that there will be more CSR disclosures in annual report of widely held companies compare to closely held companies, as a consequence of the higher level of public accountability. Conversely, in a highly concentrated ownership company, since the public interest is relatively low, the social activities may also be expected less active.

Evidence from previous study [18]supports the existence of a negative relationship between ownership concentration and the extent of voluntary disclosure in annual reports, where CSR disclosure in the study was part of non financial voluntary disclosure. However, [11] found that ownership concentration has no effect on CSR disclosure of Malaysian company annual reports. The hypothesis is as follow

H5: There is a negative association between ownership concentration and the extent of CSR disclosure in Indonesian PLCs. 


\section{Research Method}

\subsection{Sample and Data}

The sample consists of all 148 manufacturing companies listed on IDX from 2011 to 2012. Thirty three companies excluded from the sample due to incomplete information (e.g. annual reports were not available during window period) and missing data. The final sample comprises 115 with a total of 230 firms-years observations. Data was collected from annual reports of sample companies which are available in IDX website. Social responsibility information was hand-collected from any sources in annual reports wherever the information is available, for example from the CSR disclosures, corporate governance disclosures, directors' report, Chairman's statement, and notes to the financial statement.

\subsection{Dependent Variable}

The extent of CSR disclosure represents the dependent variable in the study. Following [19], the extent of CSR disclosure was measured by a CSR disclosure index based on the Global Reporting Initiative (GRI) guideline. The GRI provides a framework of the CSRrelated issues that should be disclosed in corporate annual reports. We construct a 79 items of checklist which covers 6 themes, namely Economic (9 items), Environment (30 items), Labour (14 items), Human Right (9 items), Society (8 items), and Product Responsibility (9 items). In finalizing the checklist, reference was made to the [1] rule. Some items in the checklist which were stated in the rule, i.e. policies, types of programs, and costs, related to environment, labor practices, social and community development, and product responsibilityindicated as the mandatory CSR disclosure. The numbers of these items were 30. The remaining 49 items were then indicated as voluntary CSR disclosure.

Scoring was based on the existence of the items and equally weighted. A dichotomous procedure was utilized whereby a company is scored a 1 if an item included in the checklist is disclosed and 0 if it is not disclosed. The number of item disclosed was then divided by the maximum possible score (79) to get the CSR disclosure index [7,9,11].

\subsection{Independent Variables}

Corporate governance mechanisms namely Board Size (BDSIZE), Board Independence (BIND), Audit Committee Effectiveness (ACEF), and Ownership Concentration (OWNC) are independent variables examined in the study. ACEF was measured by an index developed by [8]. The index comprises of four elements, namely composition, authority, resources, and diligence which are divided in to ten requirements. The scoring process of the index refers to [8].Scoring was based on the existence of the requirement (i.e. " 1 " and " 0 "), except for audit committee responsibility. If there is a brief statement stating a responsibility of audit committee, it will be awarded a score of 1 . If there is also an explanation on act a particular responsibility, it will be awarded a score of 2 . If a company does not disclose at all, the score will be 0 . The score of audit committee effectiveness is the sum of all requirements of which the maximum is 14 . Table 1 presents audit committee effectiveness index while Table 2 shows the operationalization of dependent and independent variables. 
Multivariate regression analysis was used to examine the relationship between the corporate governance variables and the CSR disclosures. The regression model employs is as follows:

$$
\begin{aligned}
& \mathrm{CSRD}=\beta_{0}+\beta_{1} \mathrm{BDSIZE}_{\mathrm{j}}+\beta_{2} \mathrm{BDIND}_{\mathrm{j}}+\beta_{3} \mathrm{ACEF}_{\mathrm{j}}-\beta_{4} \mathrm{OWNC}_{\mathrm{j}}+\beta_{5} \mathrm{ROA}_{\mathrm{j}}+\beta_{6} \mathrm{SIZE}_{\mathrm{j}}+ \\
& \beta_{7} \mathrm{YEAR}+e_{\mathrm{j}}
\end{aligned}
$$

The model includes two control variables, i.e. firm's size and profitability. These variables had been widely used by prior studiesin CSR reporting and expected to enhance the association between corporate governance mechanisms and CSR disclosure. Consistent to[4,5,10,19] firms size was measured by total assets,and profitability was measured by Return on Asset [5,6,7,9,11].

\begin{tabular}{|c|c|c|}
\hline Dimension & Proxies & Scoring \\
\hline Composition & $\begin{array}{c}\text { AC independence } \\
\text { - All members shall be external independent parties } \\
\text { AC expertise } \\
\text { At least one member of the AC has educational background } \\
\text { and experience in accounting or finance }\end{array}$ & $1 ; 0$ \\
\hline Authority & $\begin{array}{c}\text { AC charter } \\
\text { - Proxy statements concerning AC charter } \\
\text { AC responsibility/duty } \\
\text { - Reviewing company's financial information } \\
\text { - Reviewing external auditing activity } \\
\text { - Reviewing the effectiveness of company's internal control } \\
\text { - Reviewing company's compliance with regulations }\end{array}$ & $1 ; 2 ; 0$ \\
\hline Resources & $\begin{array}{c}\text { AC size } \\
\text { - Comprise at least three members }\end{array}$ & $1 ; 0$ \\
\hline Diligence & $\begin{array}{c}\mathrm{AC} \text { meeting } \\
\text { - } \mathrm{AC} \text { shall has a meeting at least four times in a year } \\
\mathrm{AC} \text { voluntary disclosure } \\
\text { - } \mathrm{AC} \text { reports voluntary disclosure }\end{array}$ & $1 ; 0$ \\
\hline
\end{tabular}

Table 1. Audit Committee Effectiveness (AC) Index.

Table 2. The Regression Variables.

\begin{tabular}{|c|c|}
\hline Variables & Measurement \\
\hline CRSD & CSR disclosure index \\
\hline BDSIZE & Number of board commissioners \\
\hline BDIND & Proportion of independent commissioners on board \\
\hline ACEF & AC effectiveness index (refer to Table 1) \\
\hline OWNC & $\begin{array}{c}\text { The proportion of ordinary shares held by } \\
\text { substantial shareholders (holding 5\% or more) }\end{array}$ \\
\hline ROA & Profit before tax to total assets \\
\hline SIZE & Natural logarithm of total assets \\
\hline YEAR & 1 if data are from 2011,0 if 2012 \\
\hline
\end{tabular}




\section{Results and Discussion}

\subsection{Descriptive Statistic}

Table 3 presents descriptive statistic of all sample. As can be seen in the table, the number of board of commissioners was in the range of 2 and 11, and the average board size was 4 . The proportion of independent commissioners on board was $0.38(38 \%)$, and the minimum proportion was $0.17(17 \%)$ which indicates there were still companies not complying with IDX Rule [21]. It is requiredthat all listed companies to have at least $30 \%$ of board members to be independent. Consistent to [20], listing companies in Indonesia are highly concentrated;with mean score of ownership concentration is $75.65 \%$. There are sample companies that disclose maximumin accordance to the CSR index (79 items) and audit committee effectiveness index (14). The average number of CSR itemdisclosedin annual reports is $31.37(39.70 \%)$, whileaudit committee effectiveness score of sample companies is $9.38(67 \%)$ on average.

Table 3. Descriptive Statistics of Continuous Variables.

\begin{tabular}{|l|r|r|r|r|}
\hline \multicolumn{1}{|c|}{ Variables } & \multicolumn{1}{c|}{ Min } & \multicolumn{1}{c|}{ Max } & \multicolumn{1}{c|}{ Mean } & \multicolumn{1}{c|}{ SD } \\
\hline BDSIZE & 2 & 11 & 4.14 & 1.726 \\
\hline BIND & 0.17 & 0.75 & 0.38 & 0.098 \\
\hline OWNC & 29.71 & 98.96 & 75.65 & 16.644 \\
\hline ACEF & 2 & 14 & 9.38 & 2.526 \\
\hline SIZE & 21.84 & 32.36 & 27.88 & 1.652 \\
\hline ROA & -1.50 & 63.00 & 9.73 & 12.091 \\
\hline CSR & 3 & 79 & 31.37 & 15.671 \\
\hline
\end{tabular}

Table 4 shows descriptive statistic of CSR disclosure in 2011 and 2012 as well as results of $\mathrm{t}$ statistic test. Table 4 shows that the extent of CSR disclosure generally has increased almost doubled from an average of 17.20 (21.77\%) in 2011 to $34.12(43.18 \%)$ in 2012. Table 4 also suggests that there were companies disclosed all the items in the checklist in their company annual reports in 2012. Additionally, results of the paired sample $t$-testindicate that there was a significance difference in the mean score of disclosure in 2011 and 2012 at 1 percent level (sig. $=0.00$ ). The findings show that the release of [1] rule has improve the extent of CSR disclosure in Indonesian PLCs. Hence, H1 is failed to reject.

Table 4. The Extent of CSR Disclosure: Descriptive Statistic and $t$-test.

\begin{tabular}{|c|c|c|c|c|c|c|}
\hline Year & Min & Max & Mean & SD & t & Sig \\
\hline 2011 & 3 & 50 & 17.20 & 8.308 & \multirow{2}{*}{-16.357} & 0.00 \\
\hline 2012 & 5 & 79 & 34.12 & 13.526 & & \\
\hline
\end{tabular}




\subsection{Correlation Analysis}

The collinearity between the independent variables is presented in Table 5. The Pearson correlations in the table indicate that the multicollinearity is not serious for the independent variables. As suggested by [22], that collinearity should be harmful if the correlation coefficientscoefficient exceeds 0.7 . Multicolinearity was also evaluated using the variance inflation factor (VIF) figured by the regression analysis on SPSS. Table 6 shows that VIFs of all independent variables are less than 2. According to [23], collinearity is considered a problem only when VIF is more than 10. Therefore, these findings suggest that the regression model do not indicate any serious collinearity in the examined model.

Table 5.Pearson Correlation among Continuous Independent Variables

\begin{tabular}{|l|r|r|r|r|r|r|r|}
\hline & \multicolumn{1}{|c|}{ BDSIZE } & \multicolumn{1}{c|}{ BIND } & \multicolumn{1}{c|}{ OWNC } & \multicolumn{1}{c|}{ ACEF } & \multicolumn{1}{c|}{ SIZE } & ROA & CSR \\
\hline BDSIZE & 1 & & & & & & \\
\hline BIND & 0.002 & 1 & & & & & \\
\hline OWNC & -0.080 & -0.092 & 1 & & & & \\
\hline ACEF & 0.048 & 0.155 & 0.135 & 1 & & & \\
\hline SIZE & $0.506^{* *}$ & 0.173 & $-0.270^{* *}$ & 0.179 & 1 & & \\
\hline ROA & 0.021 & -0.057 & 0.023 & -0.106 & 0.119 & & 1 \\
\hline CSR & $0.228^{*}$ & 0.138 & -0.110 & $0.246^{* *}$ & $0.346^{* *}$ & -0.034 & 1 \\
\hline
\end{tabular}

Notes: ${ }^{* *}$ Correlation is significant at the 0.01 level (2-tailed), ${ }^{*}$. Correlation is significant at the 0.05 level (2-tailed).

\subsection{Regression Analysis}

As shown in Table 6, the model which incorporates six continuous variables and one categorical variable is significant at the 1 per cent level $(\mathrm{sig}=0.003)$ and is able to explain 21.4 per centof the variations in CSR disclosure in Indonesian PLCs (Adjusted $R$-squared = 21.4 per cent) for the two year period 2011 and 2012. Audit committee effectiveness and firm's size is significant at the 5 per cent level.

Table 6.Multiple Regression Analysis Results.

\begin{tabular}{|c|c|c|c|c|}
\hline Variables & B & Significance & Tolerance & VIF \\
\hline Constant & -3.388 & 0.686 & & \\
\hline BDSIZE & 0.238 & 0.379 & 0.728 & 1.373 \\
\hline BIND & 2.671 & 0.522 & 0.937 & 1.067 \\
\hline OWNC & -0.015 & 0.545 & 0.876 & 1.141 \\
\hline ACEF & 0.344 & $0.041^{*}$ & 0.893 & 1.119 \\
\hline SIZE & 0.670 & $0.030^{*}$ & 0.621 & 1.610 \\
\hline ROA & -0.015 & 0.661 & 0.955 & 1.047 \\
\hline YEAR & 0.183 & 0.162 & 0.848 & 1.179 \\
\hline
\end{tabular}




\begin{tabular}{|l|c|c|l|l|}
\hline $\mathrm{R}^{2}$ & & 23.2 & & \\
\hline Adjusted $\mathrm{R}^{2}$ & & 21.4 & & \\
\hline F statistics & & 3.635 & & \\
\hline Significance & & $0.003^{* *}$ & & \\
\hline \multicolumn{2}{|l}{ Notes:**Sigificant at the 0.01 lovel *Significant the 0.05 level }
\end{tabular}

Notes: **Significant at the 0.01 level *Significant at the 0.05 level

The positive association between audit committee effectiveness and the extent of CSR disclosure implies that the effectiveness of audit committee is more likely to lead to better concern in corporate social activities and hence disclosure in annual reports. It may also be interpreted that an effective audit committee encourages the management to involve more in social activities and hence to disclose more in annual reports. An effective audit committee through its monitoring function may push the management to comply with mandatory CSR disclosure as stated in the [1] rule. This relates to one of the audit committee responsibilities as stated in $[24,25]$ rule that is reviewing company's compliance with regulation. The effectiveness of audit committee therefore, leads to the improvement in the extent of CSR disclosure among PLCs in Indonesia. The results appear to support[8] which found that the effectiveness of audit committee may enhance financial reporting quality in terms of its value relevance (timeliness) of financial reporting. In terms of the relation between audit committee and CSR reporting, the results seem to support [6]which found that audit committee financial expertise and audit committee meetings were positively associated with CSR disclosure.

Firm's size is positively associated and statistically significant with CSR disclosure. In Indonesian context, the significance of firm's size is consistent with [4]. Larger firms basically have more resources in order to be able to bear the cost to do more social activities. The results are consistent to [7,11] which found that company size has a positive and significant effect on CSR disclosure. According to [11], larger companies may involve in more social activitieshence CSR disclosure in order to build positive image. It may also due to their approach in managing political cost and legitimizing their existence since larger companies face more public pressure and more politically sensitive.

Profitability, board size, board indepence, and ownership concentration are found to have insignificant relationship with the extent of disclosure. The non-significance of the profitability supports $[4,5,11]$ which appears to confirm [26]'s view that social disclosure are very much linked to public pressure rather than the market place or economic pressure. Ownership concentration is not statistically significant in explaining the extent of CSR disclosure in annual reports. This implies that the majority shareholders do not influence and intervene in social activities undertaken and hence CSR report prepared by the management.

Board commissioners in terms of their size and independence are not statistically significant in influencing the extent of CSR disclosure. The non-significance of the board variables perhaps due to the role of the board has been represented by audit committee. In this research, audit committee effectiveness variable has a positive association with the extent of disclosure. As a committee of the board, the role of audit committee is to oversee financial reporting quality, including the extent of disclosure. The monitoring function of independent commissioner has been represented in the audit committee since an independent commissioner also acts as a chairman of audit committee [24, 25]. Audit Committee was formed with the primary objective to assist the Board of Commissioners in carrying out supervisory responsibilities over the financial reporting process, internal control system, the audit process, good corporate governance implementation and the process of monitoring compliance with laws and regulations on the company. The results 
are consistent to [5] which found that board size and board independence has no relationship with the extent of disclosure but the proportion of independent non-executive director sitting on audit committee has a positive relationship with the extent of CSR disclosure in annual reports.

\section{Conclusions, Limitations and Suggestion for Further Research}

This research has examined the extent of CSR disclosure in Indonesian PLCs with the expectation that after the issuance of the [1] rule which provides guidelines of what should be disclosed related to CSR in annual reports, more CSR activities would be undertaken and hence disclosed in company annual reports. The research also examined whether corporate governance mechanisms have an impact on CSR disclosure in Indonesian PLCs. As expected, the paired sample t-test suggested that there was an increase in the extent of CSR disclosure of Indonesian PLCs in 2011 as compared to 2012 and the increase was statistically significant at the 1 per cent level. This finding implies that the issuance of the [1] rule has had some positive impact on in terms of encouraging the minimum level of social activities should be carried out and hence disclosed in company annual reports. In addition, the multiple regression analysis showed that audit committee effectiveness and size were significant factors in explaining the extent of CSR disclosure in annual reports. It would appear that PLCs with a higher score of audit committee effectiveness and a higher total asset disclosed significantly more CSR information than their counterparts. This findings suggest that the involvement of audit committee through its effectiveness in overseeing company's financial reporting and the availability of more resources (assets) could lead to better concern in corporate social activities and hence disclosure in annual reports.

This study uses two-year period, i.e. 2011 and 2012 which represents the period before and after the issuance of the [1] rule respectively. Year 2012 however, is the year of immediate effect of the rule should be complied. The rule was issued in August 2012 so it took only six months for PLCs to prepare the 2012 annual reports in accordance to the regulation. It may be expected that in 2013 the extent of CSR disclosure increased as the time to engage of social activities is longer than in 2012. Additionally, this study uses manufacturing companies as a sample, hence the findings may not be generalized to all Indonesian PLCs. Future research in CSR disclosure may perform a longitudinal analysis to portray the trend in CSR reporting in Indonesian PLCs. Extending the analysis to included other factors that may relate to CSR disclosure in the model may also be encouraged as the $\mathrm{R}^{2}$ of the regression analysis is relatively low.

\section{References}

1. Bapepam-LK Rule No. No. X.K.6 (attachment to the decision of the Chairman of Bapepam-LK No. Kep-431/BL/2012, dated 1 August 2012) on Submission of Issuer or Public Company Annual Reports (2012)

2. Bapepam-LK Rule No. No. X.K.6 (attachment to the decision of the Chairman of Bapepam-LK No. Kep-134/BL/2006, dated 7 December 2006) on Submission of Issuer or Public Company Annual Reports (2006)

3. E. Mirfazli, Int. J. of Isl. and Midd. East. Fin. and Manag.1, 275-284 (2008)

4. S.V. Siregar, Y. Bahtiar, Int. J. Isl. and Midd. East. Fin. and Manag. 3, 241-252 (2010)

5. R. Said, Y. Hj Zainuddin, H. Haron, Soc. Resp. J. 5, 212-226 (2009)

6. M. I. Jizi, A. Salama, R. Dixon, R. Stratling, J. Bus. Ethics125, 601-615 (2013)

7. A. Khan, M.B. Muttakin, J. Siddiqui, J. Bus. Ethics 114, 207-223 (2013) 
8. S.R. Ika, N.A. Mohd Ghazali, Man. Aud. J. 27, 403-424 (2012)

9. E. Esa, N.A. Mohd Ghazali, Corp. Gov. 12, 292-305 (2012)

10. G. Giannarakis, Soc. Resp. J. 10,569-590 (2014)

11. N.A. Mohd Ghazali, Corp. Gov. 7, 251-266 (2007)

12. P. Collier, A. Gregory, J. Acc Pub. Pol. 18, 311-322(1999)

13. M. Jensen, J. Fin. 3, 305-360 (1993)

14. S.T. Petra, Corp. Gov. 5, 55-64 (2005)

15. S. Turley, M. Zaman, J. Man. Gov. 8, 305-332 (2004)

16. S. Turley, M. Zaman, Acct. Aud. Account.J. 20, 765-788 (2007)

17. M. Mangena, R. Pike, Acct Bus Res. 35,327-349 (2005)

18. M. Hossain, L.M. Tan, M. Adams, Int J. Acc. 29, 334-351 (1994)

19. R. Gamerschlag, K.Möller, F.Verbeeten, Rev. Manag. Sc. 5, 233-262 (2011)

20. W. E. Daniel, Bond Law Rev 5, 345-347 (2003)

21. IDX. The Decision of Directors of JSX No. Kep-315/BEJ/06-2000 concerning Independent Directors, Audit Committee, and Corporate Secretary, Indonesia Stock Exchange, Jakarta (2000)

22. B.G.Tabahnick, L.S. Fidell, Using Multivariate Statistics, $4^{\text {th }}$ ed. (Allyn and Bacon, Boston, 2001)

23. D.N. Gujarati, Basic Econometrics, $3^{\text {rd }}$ ed. (McGraw-Hill, New York, 2005)

24. Bapepam Rule No. 29/PM/2004 concerning Guidelines for Establishment and Working Implementation of Audit Committee (2004).

25. Bapepam-LK Rule No. Kep-634/BL/2012 and the Annex of Regulation IX.1.5 on the Establishment and Implementation Guidance of the Audit Committee (2012)

26. S. Williams, Int. Jour. Acc. 34, 209-238 (1999) 